\title{
The impact of distance cataract surgical wet laboratory training on cataract surgical competency of ophthalmology residents
}

\author{
Amelia Geary ${ }^{1 *}$, Qing Wen², Rosa Adrianzén ${ }^{3,4}$, Nathan Congdon', R. Janani ${ }^{5}$, Danny Haddad ${ }^{1}$, \\ Clare Szalay Timbo ${ }^{1}$ and Yousuf M. Khalifa ${ }^{6}$
}

\begin{abstract}
Background: This study assessed the impact of distance cataract surgical wet laboratory training on surgical competency of ophthalmology residents at a tertiary-level ophthalmic training center in Trujillo, Peru.

Methods: Three five-week distance wet lab courses were administered through Cybersight, Orbis International's telemedicine platform. Weekly lectures and demonstrations addressed specific steps in phacoemulsification surgery. Each lecture had two accompanying wet lab assignments, which residents completed and recorded in their institution's wet lab and uploaded to Cybersight for grading. Competency was assessed through anonymous grading of pre- and post-training surgical simulation videos, masked as to which occurred before and after training, using a standardized competency rubric adapted from the Ophthalmology Surgical Competency Assessment Rubric (OSCAR, scale of 0-32). Day one best-corrected post-operative visual acuity (BVCA) was assessed in the operative eye on the initial consecutive 4-6 surgeries conducted by the residents as per the norms of their residency training. An anonymous post-training satisfaction survey was administered to trainees'.

Results: In total, 21 ophthalmic residents participated in the courses, submitting a total of 210 surgical videos. Trainees' average competency score increased 6.95 points (95\% $[4.28,9.62], S D=5.01, p<0.0001$, two sample ttest) from $19.3(95 \% \mathrm{Cl}[17.2,21.5], \mathrm{SD}=4.04)$ to $26.3(95 \% \mathrm{Cl}[24.2,28.3], \mathrm{SD}=3.93)$. Visual acuity for $92 \%$ of posttraining resident surgeries $(n=100)$ was $\geq 20 / 60$, meeting the World Health Organization's criterion for good quality.

Conclusions: Structured distance wet lab courses in phacoemulsification resulted in significantly improved cataract surgical skills. This model could be applicable to locations where there are obstacles to traditional in-person training, such as the current COVID-19 pandemic.
\end{abstract}

Keywords: Cataract surgical training, Ophthalmic residency training, Simulation, Mentorship, Distance-learning, COVID - 19

\footnotetext{
* Correspondence: amelia.geary@orbis.org

${ }^{1}$ Orbis International, 520 8th Avenue, Floor 12, New York, NY 10018, USA

Full list of author information is available at the end of the article
}

C C The Author(s). 2021 Open Access This article is licensed under a Creative Commons Attribution 4.0 International License, which permits use, sharing, adaptation, distribution and reproduction in any medium or format, as long as you give appropriate credit to the original author(s) and the source, provide a link to the Creative Commons licence, and indicate if changes were made. The images or other third party material in this article are included in the article's Creative Commons licence, unless indicated otherwise in a credit line to the material. If material is not included in the article's Creative Commons licence and your intended use is not permitted by statutory regulation or exceeds the permitted use, you will need to obtain permission directly from the copyright holder. To view a copy of this licence, visit http://creativecommons.org/licenses/by/4.0/ The Creative Commons Public Domain Dedication waiver (http://creativecommons.org/publicdomain/zero/1.0/) applies to the data made available in this article, unless otherwise stated in a credit line to the data. 


\section{Background}

Lack of human resources in eye care delivery is a global problem. At present, there are not enough ophthalmologists capable of performing high-quality cataract surgery to meet the need, which is growing due to expansion and aging of the global population [1, 2]. The burden of unoperated cataract is unfairly borne by populations of low and middle-income countries (LMICs), where the lack of trained ophthalmologists is most acute [3]. Among existing ophthalmologists in low-resource settings, many do not operate at all, or have low surgical output [4]. Additionally, visual outcomes of cataract surgery in many LMICs fail to meet the World Health Organization's (WHO) recommended standards [5].

This lack of ophthalmologists is not limited to lowincome countries. While a third of ophthalmologists worldwide practice in the USA, Russia, and China and there is a global rise in the total number, the growing and aging population in many high-income countries is growing faster than the number of ophthalmologists. These aging populations will put pressure on current ophthalmic service providers globally, resulting in challenges in training enough doctors in the coming years [1].

While training is crucial to meeting the growing need for surgical services in eye care [6], the majority of residents in many settings, including those at high volume and well-staffed teaching hospitals, are not receiving adequate hands-on surgical training to ensure competency in cataract surgery [7], with some receiving none at all $[8,9]$. One approach to improved surgical skills and the delivery of hands-on training has been surgical simulation training via a wet/dry lab. Surgical simulation can reduce the learning curve of difficult surgical techniques, accelerate the rate for trainees to achieve surgical competency, and improve patient safety [10]. However, there are challenges to the delivery of surgical simulation training reported by both low/middle-income and highincome countries alike [11, 12], including the absence of structured simulation training programs and the lack of trained instructors or personnel [13].

The current paper reports on a novel and scalable model for cataract surgical training: distance wet labs. Data are presented on masked, anonymous assessments of surgical videos before and after training, to determine whether this approach could lead to objectively measurable improvements in surgical competency.

\section{Methods}

The La Libertad region of Peru is the third most populous in the country, with 1,617,050 inhabitants, 50\% of whom live in the capital city of Trujillo. The majority of heath care workers in the Peru Northern zone (population approximately 4.5 million) are based in Trujillo [14]. The regional population is aging rapidly due to a reduction in the fertility rate and rising life expectancy [15], increasing the number at risk for cataract blindness. Some $58 \%$ of the estimated 150,000 blind persons in Peru have lost sight from unoperated cataract, and cataract surgical coverage is only $63 \%$ [16].

In 2017, Orbis International partnered with the Instituto Regional De Oftalmología Javier Servat Univazo (IRO) in Trujillo to pilot new methods of delivering cataract surgical training, which could be added to their existing resident training norms and residency curriculum. IRO is staffed by 25 ophthalmologists and 17 residents, serves as the main eye care referral center for La Libertad and the Northern Peru Zone and is the second largest training institute in ophthalmology in the country which accepts international residents from throughout Latin America. In 2016, the hospital had 135,969 outpatient visits, and performed 6841 surgeries, of which, 2254 were cataract surgeries [17]. IRO was also the first teaching hospital in Latin America to receive the International Council of Ophthalmology Accreditation as an "Advanced Surgical Training Program."

Despite the fact that IRO is a busy hospital with a large faculty, residents were not receiving adequate cataract surgical training in phacoemulsification. Some of the reasons shared by the faculty were: high clinic volume keeping both faculty and residents occupied, the majority of senior faculty are unavailable in the afternoons, when they work in their private sector to supplement low government wages ( $\$ 1000 /$ month $)$ and therefore not readily available for training, and residents only start practicing phacoemulsification in their final year, limiting the number of cases they receive. These same issues are seen in other large hospitals, where consultants invest minimal time in training residents and busy clinics keep residents occupied, leaving little additional time for wet lab training [18].

As part of this partnership, Orbis and IRO began delivering structured distance wet lab courses in phacoemulsification for residents to improve their cataract surgical skills. No other changes to the residency curriculum were made besides the introduction of the five-week wet lab training in phacoemulsification. Orbis partnered with Emory University in Atlanta, USA, and IRO to deliver three distance wet lab surgical courses targeting residents in their second or final years of training. The first course was held in January-February 2017 for five residents, the second course in October-November 2017 for 7 residents and the third course in October 2018 for 9 residents. A structured course was developed to mimic the in-person wet lab training delivered to Emory ophthalmology residents. The training was administered by a mentor from Emory Eye Center (YK) and a course director at IRO (RA), and was delivered through Cybersight, Orbis' telemedicine and learning 
platform, which is hosted on a mobile responsive learning management system (LMS). The LMS allows for curriculum creation, interactivity between learners and mentors, task assignment, and the grading and tracking of learners' progress and results. Ethics approval was obtained from the Institutional Review Board at IRO, written consent was obtained from the leadership of IRO and the tenets of the Declaration of Helsinki were followed throughout.

The residency program at IRO introduces phacoemulsification surgery in the final year of training. Second year residents practice manual small incision cataract surgery or extracapsular cataract extraction. Therefore, final year residents were selected for the first and second distance wet lab courses. For the third course, second year residents were also included, as IRO faculty decided they wanted residents to participate in the course twice, once in the second and once in their final year of residency. All residents were new to phacoemulsification surgery when enrolled in the course, having no prior experience performing such cases in the operating room.

Prior to the course, an orientation was given to residents to familiarize them with Cybersight, including information on registering for and accessing the course; recording and uploading assignments; initiating online communication with the mentor; and obtaining other available open-source educational materials. Remote testing of the internet speed and bandwidth in Trujillo was completed by the information technology staff at IRO and Orbis. A minimum Internet connection of 3 Mbps upload and download is desirable for real-time video and uploading recorded wet lab video assignments, similar to the requirements for watching YouTube videos. However, it is possible to use systems that can adapt to lower bandwidth/slower internet connections, which Orbis has deployed in other project locations.

The course was designed to run for 5 weeks, with each week addressing specific, sequential steps in phacoemulsification surgery (Table 1). The mentor delivered weekly lectures and demonstrations by live video conference. Conferences were interactive, with opportunities for questions, quizzing of students and repetition of demonstrations when requested. Each lecture had two accompanying wet lab assignments, for a total of 10 assignments. Residents had 4 days to practice, complete and record their assignments on video in the IRO wet lab. Practice was self-paced and determined by the resident. Assignments were conducted on either animal eyes, Kitaro ${ }^{\circ}$ Wet Lab kit (FCI Ophthalmics, Marshfield Hills, MA., USA) simulation eyes or Philips Studio artificial eyes (Bristol, UK). With the first course, sessions 1 and 2 were performed with animal eyes and the remaining three sessions with model eyes. In the second and third course, all sessions were done with model eyes with the exception of session one.

Once completed, residents uploaded their video assignments to the Cybersight platform for grading by the course mentor (YK). The system automatically prompted the mentor to review and grade each resident's assignment directly on the Cybersight platform. All grading was done against the Ophthalmology Simulated Surgical Competency Assessment Rubric (OSSCAR) [19], a standardized competency rubric adapted from the International Council of Ophthalmology's Ophthalmology Surgical Competency Assessment Rubric (ICO-OSCAR) [20].

Table 1 Tele-medicine Phacoemulsification Wet Lab Cataract Surgery Course

\begin{tabular}{|c|c|c|c|c|}
\hline Week & Model & \# of Eyes per Resident & $\begin{array}{l}\text { Topic and Specific Steps } \\
\text { in the OSCAR Rubric }\end{array}$ & Video Assignment \\
\hline 0 & Artificial Eye & 3 eyes each & Pre-course videos & $\begin{array}{l}\text { Upload three complete Phaco simulation cases to Cybersight } \\
\text { per participant }\end{array}$ \\
\hline 1 & Pig Eye & 5 eyes each & $\begin{array}{l}\text { Competency } 1 \text { \& } 2 \\
\text { Paracentesis, Keratome, } \\
\text { Cannula }\end{array}$ & $\begin{array}{l}\text { Video One: } 20 \text { Paracenteses, and enter with cannula through } \\
\text { paracentesis port } 20 \text { times } \\
\text { Video Two: } 20 \text { Keratome incisions }\end{array}$ \\
\hline 2 & Artificial Eye & $\begin{array}{l}1 \text { eye each plus sufficient } \\
\text { film to practice }\end{array}$ & $\begin{array}{l}\text { Competency } 3 \text { \& } 4 \\
\text { Centration, Capsulorhexis }\end{array}$ & $\begin{array}{l}\text { Video Three: } 30 \text { repetitions of dominant and non-dominant } \\
\text { hand instrument movement in the anterior chamber } \\
\text { Video Four: } 10 \text { Capsulorhexis }\end{array}$ \\
\hline 3 & Artificial Eye & 10 eyes each & $\begin{array}{l}\text { Competency } 5 \& 6,14 \\
\text { Hydrodissection, } \\
\text { Nucleus rotation, Grooving }\end{array}$ & $\begin{array}{l}\text { Video Five: } 10 \text { Hydrodissections; } 10 \text { Nucleus rotations in the } \\
\text { bag; } \\
\text { Video Six: } 5 \text { Maltese Crosses to } 80 \% \text { depth }\end{array}$ \\
\hline 4 & Artificial Eye & 7 eyes each & $\begin{array}{l}\text { Competency } 7,8,9,10,15 \\
\text { Nucleus Disassembly, } \\
\text { Quadrant Removal }\end{array}$ & $\begin{array}{l}\text { Video Seven: } 3 \text { Nucleus disassembles with quadrant removal } \\
\text { Video Eight: An additional } 2 \text { nucleus disassembles with } \\
\text { quadrant removal }\end{array}$ \\
\hline 5 & Artificial Eye & $\begin{array}{l}3 \text { eyes each (can reuse } \\
\text { from the previous week) }\end{array}$ & $\begin{array}{l}\text { Competency } 11,12,13,16 \\
\text { Irrigation/Aspiration, } \\
\text { intra-ocular lens insertion }\end{array}$ & $\begin{array}{l}\text { Video 9: } 5 \text { Use of irrigation/aspiration } \\
\text { Video 10: } 3 \text { intra-ocular lens insertions in the bag }\end{array}$ \\
\hline 6 & Artificial Eye & 3 eyes each & Post-course videos & $\begin{array}{l}\text { Upload three complete Phacoemulsification simulation cases } \\
\text { to Cybersight per participant }\end{array}$ \\
\hline
\end{tabular}


Table 2 Ophthalmic Simulated Surgical Competency Assessment Rubric (OSSCAR)- Phacoemulsification

\begin{tabular}{|c|c|c|c|c|c|}
\hline & & $\begin{array}{l}\text { Novice } \\
(\text { score }=0)\end{array}$ & $\begin{array}{l}\text { Advanced Beginner } \\
(\text { score }=1)\end{array}$ & $\begin{array}{l}\text { Competent } \\
(\text { score }=2)\end{array}$ & $\begin{array}{l}\text { Score }(\text { Not } \\
\text { done } \\
\text { score }=0 \text { ) }\end{array}$ \\
\hline 1 & $\begin{array}{l}\text { Incision and paracentesis } \\
\text { formation technique }\end{array}$ & $\begin{array}{l}\text { Poor wound construction } \\
\text { and paracentesis } \\
\text { placement. Traumatizes } \\
\text { conjunctiva }\end{array}$ & $\begin{array}{l}\text { Correct positioning of } \\
\text { incision and paracentesis } \\
\text { but incision architecture } \\
\text { is not yet correct }\end{array}$ & $\begin{array}{l}\text { Well-constructed incision } \\
\text { and paracentesis with } \\
\text { careful tissue handling }\end{array}$ & \\
\hline 2 & $\begin{array}{l}\text { Viscoelastic: appropriate use } \\
\text { and safe insertion }\end{array}$ & $\begin{array}{l}\text { Incomplete fill }+/- \\
\text { damage to capsule }\end{array}$ & $\begin{array}{l}\text { Appropriate fill but still } \\
\text { hesitant }\end{array}$ & $\begin{array}{l}\text { Safe and smooth insertion } \\
\text { of viscoelastic }\end{array}$ & \\
\hline 3 & $\begin{array}{l}\text { Capsulorhexis: Commencement } \\
\text { of flap }\end{array}$ & $\begin{array}{l}\text { Poor positioning of initial } \\
\text { flap with disruption of } \\
\text { underlying cortex }\end{array}$ & $\begin{array}{l}\text { Good positioning of flap } \\
\text { but slightly hesitant in } \\
\text { raising the flap }\end{array}$ & $\begin{array}{l}\text { Neat creation of a flap of } \\
\text { an appropriate size in the } \\
\text { correct position. }\end{array}$ & \\
\hline 4 & $\begin{array}{l}\text { Capsulorhexis: Formation and } \\
\text { circular completion }\end{array}$ & $\begin{array}{l}\text { Unable to create a } \\
\text { complete capsulorhexis } \\
\text { with poor understanding } \\
\text { of tearing vectors }\end{array}$ & $\begin{array}{l}\text { Capsulorhexis is } \\
\text { completed but is either } \\
\text { too small, too large or } \\
\text { eccentric }\end{array}$ & $\begin{array}{l}\text { Smooth creation of an } \\
\text { appropriately sized and } \\
\text { circular capsulorhexis }\end{array}$ & \\
\hline 5 & $\begin{array}{l}\text { Hydrodissection: visible fluid } \\
\text { wave and free nuclear rotation }\end{array}$ & $\begin{array}{l}\text { Cannot insert cannula in } \\
\text { the correct tissue plane / } \\
\text { excessive or insufficient } \\
\text { force used / incomplete } \\
\text { freeing of the nucleus }\end{array}$ & $\begin{array}{l}\text { Cannula inserted correctly } \\
\text { under the anterior capsule } \\
\text { but more than one } \\
\text { attempt is needed to } \\
\text { achieve free nucleus } \\
\text { rotation }\end{array}$ & $\begin{array}{l}\text { Efficient and safe } \\
\text { hydrodissection with free } \\
\text { nuclear rotation }\end{array}$ & \\
\hline 6 & $\begin{array}{l}\text { Phaco probe and second } \\
\text { instrument: effective use and } \\
\text { stability within the eye }\end{array}$ & $\begin{array}{l}\text { Unsure of the positioning } \\
\text { of the instruments within } \\
\text { the eye / phaco probe } \\
\text { is frequently close to the } \\
\text { capsulorhexis / inefficient } \\
\text { use of the second } \\
\text { instrument }\end{array}$ & $\begin{array}{l}\text { Phaco probe and second } \\
\text { instrument generally } \\
\text { positioned correctly / no } \\
\text { iris trauma / capsulorhexis } \\
\text { not endangered }\end{array}$ & $\begin{array}{l}\text { Confident instrument } \\
\text { handling with phaco } \\
\text { probe always kept in a } \\
\text { safe position }\end{array}$ & \\
\hline 7 & $\begin{array}{l}\text { Nucleus: sculpting or primary } \\
\text { chop }\end{array}$ & $\begin{array}{l}\text { Hesitant use of the } \\
\text { phaco probe / tendency } \\
\text { to push the lens / timid } \\
\text { sculpting with poor use } \\
\text { of full range of phaco } \\
\text { power }\end{array}$ & $\begin{array}{l}\text { More efficient use of } \\
\text { phaco power and } \\
\text { appropriate vacuum } \\
\text { settings to create a groove } \\
\text { or perform a primary } \\
\text { chop / still some stress } \\
\text { placed on zonules }\end{array}$ & $\begin{array}{l}\text { Fast and efficient sculpting } \\
\text { or chopping technique }\end{array}$ & \\
\hline 8 & $\begin{array}{l}\text { Nucleus: Rotation and } \\
\text { manipulation }\end{array}$ & $\begin{array}{l}\text { Incorrect positioning of } \\
\text { the instruments / } \\
\text { excessive posterior } \\
\text { pressure on the lens / } \\
\text { rounds off the edges of } \\
\text { the quadrants leaving a } \\
\text { bowl }\end{array}$ & $\begin{array}{l}\text { Good positioning of } \\
\text { instruments but still some } \\
\text { hesitancy using the second } \\
\text { instrument / some } \\
\text { posterior pressure whilst } \\
\text { rotating the nucleus }\end{array}$ & $\begin{array}{l}\text { Confident use of both } \\
\text { phaco probe and second } \\
\text { instrument to rotate the } \\
\text { lens with no posterior } \\
\text { pressure on the zonules }\end{array}$ & \\
\hline 9 & Nucleus: cracking or chopping & $\begin{array}{l}\text { Attempts to crack the } \\
\text { lens before groove is } \\
\text { deep enough / places } \\
\text { instruments too } \\
\text { superficially in the groove } \\
\text { / excessive posterior } \\
\text { pressure during cracking }\end{array}$ & $\begin{array}{l}\text { Forms a grove of the } \\
\text { correct depth and width } \\
\text { before cracking / still } \\
\text { requires several attempts } \\
\text { to crack the nucleus }\end{array}$ & $\begin{array}{l}\text { Good groove construction } \\
\text { and cracks / chops nucleus } \\
\text { at first attempt }\end{array}$ & \\
\hline 10 & Nucleus: segment removal & $\begin{array}{l}\text { Chases segments with } \\
\text { phaco probe / poor use } \\
\text { of the second instrument } \\
\text { / endangers capsule / } \\
\text { phaco probe positioned } \\
\text { too close to posterior } \\
\text { capsule or endothelium }\end{array}$ & $\begin{array}{l}\text { Appropriate use of } \\
\text { vacuum to engage } \\
\text { segments / second } \\
\text { instrument being used } \\
\text { more efficiently / less of a } \\
\text { tendency to phaco too } \\
\text { deep in capsular bag or } \\
\text { too close to the } \\
\text { endothelium }\end{array}$ & $\begin{array}{l}\text { Safe engagement of } \\
\text { nuclear segments and } \\
\text { efficient removal with } \\
\text { good use of the second } \\
\text { instrument }\end{array}$ & \\
\hline 11 & $\begin{array}{l}\text { Irrigation and aspiration } \\
\text { technique with adequate } \\
\text { removal of cortex }\end{array}$ & $\begin{array}{l}\text { Aspiration port not safely } \\
\text { positioned in the } \\
\text { capsular bag / inappropriate } \\
\text { vacuum used / hesitant }\end{array}$ & $\begin{array}{l}\text { Better positioning of } \\
\text { aspiration port / still not } \\
\text { using vacuum efficiently / } \\
\text { occasionally engages the }\end{array}$ & $\begin{array}{l}\text { Efficient removal of the } \\
\text { cortex with no danger to } \\
\text { the capsular bag or } \\
\text { capsulorhexis }\end{array}$ & \\
\hline
\end{tabular}


Table 2 Ophthalmic Simulated Surgical Competency Assessment Rubric (OSSCAR)- Phacoemulsification (Continued)

\begin{tabular}{|c|c|c|c|c|c|}
\hline & & $\begin{array}{l}\text { Novice } \\
(\text { score }=0)\end{array}$ & $\begin{array}{l}\text { Advanced Beginner } \\
(\text { score }=1)\end{array}$ & $\begin{array}{l}\text { Competent } \\
(\text { score }=2)\end{array}$ & $\begin{array}{l}\text { Score (Not } \\
\text { done } \\
\text { score }=0 \text { ) }\end{array}$ \\
\hline 12 & $\begin{array}{l}\text { Lens insertion, rotation and } \\
\text { final position of IOL }\end{array}$ & $\begin{array}{l}\text { IOL not placed in the capsular } \\
\text { bag / unable to rotate the } \\
\text { lens into the correct position }\end{array}$ & $\begin{array}{l}\text { IOL placed in the capsular } \\
\text { bag but haptics still require } \\
\text { manipulation }\end{array}$ & $\begin{array}{l}\text { IOL completely placed } \\
\text { within the capsular bag } \\
\text { at the first attempt }\end{array}$ & \\
\hline 13 & $\begin{array}{l}\text { Wound closure: hydration, } \\
\text { suturing if required and } \\
\text { checking security }\end{array}$ & $\begin{array}{l}\text { Ineffective hydration technique } \\
\text { / does not check would } \\
\text { security / poor placement } \\
\text { and tying of } 10 / 0 \text { suture }\end{array}$ & $\begin{array}{l}\text { Wound hydration performed } \\
\text { correctly / suture tying } \\
\text { hesitant / suture slightly too } \\
\text { tight or too loose }\end{array}$ & $\begin{array}{l}\text { Wound hydration } \\
\text { performed correctly / } \\
\text { good suturing technique } \\
\text { with correct tension }\end{array}$ & \\
\hline \multicolumn{6}{|c|}{ Global Indices } \\
\hline 14 & Tissue handling: & $\begin{array}{l}\text { Tissue handling is often unsafe } \\
\text { with inadvertent damage to } \\
\text { the conjunctiva, cornea, iris } \\
\text { or capsule/excessively } \\
\text { aggressive or timid. }\end{array}$ & $\begin{array}{l}\text { Tissue handling is safe but } \\
\text { sometimes requires multiple } \\
\text { attempts to achieve desired } \\
\text { manipulation of tissue. }\end{array}$ & $\begin{array}{l}\text { Tissue handling is efficient, } \\
\text { fluid and almost always } \\
\text { achieves desired tissue } \\
\text { manipulation on first attempt. }\end{array}$ & \\
\hline 15 & $\begin{array}{l}\text { Eye positioning and use of the } \\
\text { microscope }\end{array}$ & $\begin{array}{l}\text { Eye is frequently in an } \\
\text { eccentric position. Focusing } \\
\text { and } X-Y \text { movement of the } \\
\text { microscope is erratic. }\end{array}$ & $\begin{array}{l}\text { Eye is mainly kept in a central } \\
\text { position and focusing of the } \\
\text { microscope is becoming } \\
\text { smoother. }\end{array}$ & $\begin{array}{l}\text { Eye is maintained in a central } \\
\text { position throughout the } \\
\text { procedure and the point of } \\
\text { interest is always in focus. }\end{array}$ & \\
\hline 16 & $\begin{array}{l}\text { Overall speed and fluidity of } \\
\text { the procedure }\end{array}$ & $\begin{array}{l}\text { Hesitant and lacks fluidity with } \\
\text { multiple pauses between } \\
\text { maneuvers }\end{array}$ & $\begin{array}{l}\text { Beginning to string the } \\
\text { different steps together with } \\
\text { minimal guidance from trainer }\end{array}$ & $\begin{array}{l}\text { All steps completed in a timely } \\
\text { manner with minimal input } \\
\text { from trainer }\end{array}$ & \\
\hline
\end{tabular}

The OSSCAR (Table 2) has 16 steps, compared to the ICO-OSCAR, which has 20 steps. Steps not appropriate for or considered too advanced for the wet lab setting were removed, including step 1 on draping, step 15 on minimizing eye rolling and corneal distortion, step 18 on intraocular spatial awareness and step 19 on iris protection. Other steps were combined, such as step 7 and 8 on use of the phacoemulsification probe and second instrument; and some steps were broken down into two parts, such as step 11 on chopping and phacoemulsification of the nucleus. All 16 steps of the OSSCAR were covered in the course. The OSSCAR has three possible grades (0-2) for each surgical step, corresponding respectively to Novice, Advanced Beginner and Competent (total grading scale $0-32$ ). The ICO-OSCAR by comparison has four grades (2-5), corresponding to Novice, Beginner, Advanced Beginner and Competent (total grading scale $0-100$ ).

A passing score of 1 on the 0-2-point scale ("Advanced Beginner") for each surgical step was necessary to continue to the next step; anything less required the resident to redo and resubmit the assignment. Residents could access their grades and communicate directly with the course mentor via the Cybersight platform, receiving unstructured, informal feedback in an ongoing manner for each assignment and on their overall performance.

Upon completion of the course, the course director and residency director received a comprehensive digital report generated by Cybersight on each resident's weekly performance, including their grades for each assignment. Residents who successfully completed the course received a certificate of completion, automatically generated by Cybersight.

Orbis tracked the surgical outcomes of first consecutive 4-6 phacoemulsification surgeries conducted by participating residents after they completed the course. Orbis also retrospectively collected the surgical outcomes for the first 4-6 surgeries performed by senior year residents in the 2 years prior (2015-2016) to the first distance wet lab surgical course, to measure the training impact on residents' real-world performance. Hands-on surgical training was conducted as per the norms of the residency program, with all surgeries being performed under the supervision of experienced consultants. Management of complications was done per partners' clinical norms and standards. Nurse technicians measured and recorded the best-corrected day one post-operative visual acuity in the operative eye. We did not exclude results of patients with systemic or ocular comorbidities but took the first cases in sequential order for each resident performing cataract surgery using phacoemulsification after training. This reflects practice patterns at IRO where residents perform many surgeries on cases of patients with comorbidities.

Also, a self -administered course satisfaction survey developed by the investigators was shared with all resident participants to capture their feedback on course content, format, acceptability and self-assessment of improvements in their skill. Learners rated their level of agreement on a 5 -point Likert scale, with 1 representing strongly disagree and 5 representing strongly agree. The 
survey was administered anonymously, using the Typeform platform (Typeform, Barcelona, Spain).

In addition, adjustments were made following the piloting of the first course, and the second and third courses (which enrolled 16 residents) included two further assignments, asking residents to upload three pre and three post-training cataract surgical simulation videos made using model eyes and covering all steps of the OSSCAR. Pre-course videos were uploaded within the week prior to beginning the course and post-course videos within 1 week after course completion. These videos were sent for anonymous grading using the OSSCAR competency rubric. The grader (RJ), an experienced ophthalmic surgeon, was masked as to which videos were recorded before and after training.

\section{Statistical methods}

The difference between pre and post-course video overall grading was analyzed using the two-tailed paired sample t-test. To evaluate the impact of the training course on specific surgical steps assessed using OSSCAR, the Wilcoxon signed-rank tests were performed for each of the 16 MSIC surgical steps pre and post course. The training impact on the quality of surgical outcomes pre and post course introduction, was analysed using a two-proportion test. All statistical analyses were done in $\mathrm{R}$ version 3.6.1 (2019-07-05) (The R Foundation; Vienna, Austria).

\section{Results}

We did not find significant differences in the performance of second- and third-year residents participating in the remote wet labs and as such, have combined their results. In total, 21 residents participating in the two courses, submitted a total of 210 surgical videos. A score of $\geq 1$ was achieved on 205 (97.6\%) assignments on the first submission, and 21 certificates of completion (100\%) were awarded. A post-course satisfaction survey reported that $100 \%$ of residents would recommend the training to others, and all confirmed a desire to participate in similar future distance surgical mentorship wet labs.

Visual acuity was measured for 100 post-training resident phacoemulsification surgeries (one second-year resident has not yet performed phacoemulsification cases due to being on an outreach rotation), of which 92 (92\%) had day one post-operative best corrected VA $\geq 20 / 60$, meeting the WHO criterion for cataract surgical quality [21]. Once again, we did not find significant variations between the three wet lab classes, in their postoperative outcomes (range 91-93\% best corrected visual acuity (BCVA) $\geq 20 / 60$ ). We analyzed patient outcomes of the first phacoemulsification surgeries $(N=44)$ performed by residents $(N=9)$ in 2015 and 2016, prior to when the distance surgical wet lab training began and found that $75 \%$ (33) had a day one post-operative BCVA $\geq 20 / 60$. This represents a $22.7 \%$ relative improvement in surgical outcomes, (an absolute increase of 17\% (95\% CI $1.5-32.5 \%, P=0.012$, two-proportions test)) for second and final year residents having taken the course over final year residents in the previous 2 years.

Patients ranged in age from 19 to 95 years, with the mean (standard deviation) age being 70 (11.9) years, and $42(42.0 \%)$ of the patients were men. A total of 55 $(55.0 \%)$ patients presented with one or more systemic or ocular comorbidity, most commonly diabetes $(n=19$, $19.0 \%)$, hypertension ( $n=16,16.0 \%)$, and suspected glaucoma $(n=8,8.0 \%)$ (Fig. 1). BCVA ranged from light perception to $20 / 30$, with a median of $20 / 100$ and interquartile range of $(20 / 60,20 / 400)$, while comparable values for post-operative visual acuity in the operative eye were light perception to 20/20; median: 20/30; interquartile range (20/25, 20/50). (Fig. 2). Unfortunately, existing medical records did not document the type of cataract in a fashion that we felt was sufficiently consistent for analysis and publication.

Sixteen residents each uploaded three pre and three post-training videos for anonymous grading following the second and third course, for a total of 96 videos. Among these, 95 (99.0\%) were graded, due to the low image quality of one pre-course video. The mean score was $26.3(95 \% \mathrm{CI}[24.2,28.3], \mathrm{SD}=3.93)$ for the postcourse videos grading, an increase of 6.95 (95\% CI [4.28, 9.62], $\mathrm{SD}=5.01, p<0.0001$, two sample t-test) compared to the mean score of $19.3(95 \% \mathrm{CI}[17.2,21.5], \mathrm{SD}=4.04)$ for pre-course videos.

Eight out of 16 total surgical steps (50\%) showed significant improvement $(p<0.05$, two-sided Wilcoxon signedrank test). The steps showing greatest improvement $(P<$ 0.007 , effect size $r>0.70$ ) were: Lens insertion, rotation and final position of intraocular lens (IOL), $P=0.000381$, median (pre-course: 0 , post-course: 1.67 ), effect size $=$ 0.895; irrigation and aspiration technique with adequate removal of cortex $P=0.000438$, median (pre-course: 0 , post-course: 2 ), effect size $=0.886$; and capsulorhexis formation and circular completion $P=0.00628$, median (precourse:1.58, post-course: 2 ), effect size $=0.721$.

\section{Discussion}

Participation in the course was associated with a significant improvement in participating residents' cataract surgical scores. This is consistent with Dean et al.'s multicentre, parallel-group randomised clinical educationintervention trial, which measured cataract surgical competency using a similar modified ICO-OSCAR. This study demonstrated statistically significant improved surgical competency after a 5-day intensive simulation training course using model eyes for the intervention group and between the intervention and control group. The difference in OSSCAR scores was 16.6 points higher 


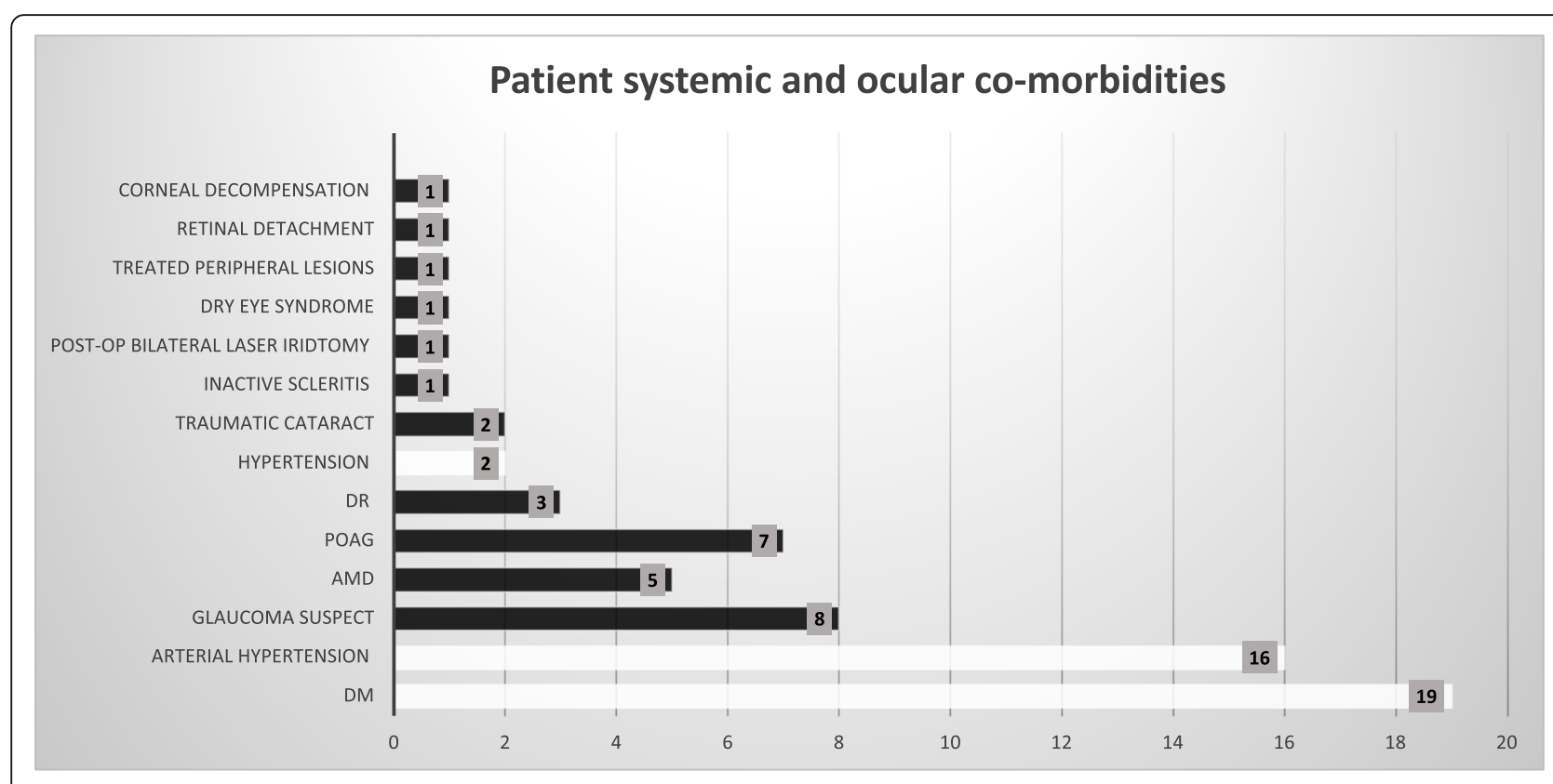

Fig. 1 Patient systemic and ocular co-morbidities

in the intervention group (95\% CI, 14.4-18.7) with adjustment for baseline scores $(P<.001)$ [22].

Post course surgical visual outcomes met WHO standards for cataract surgical quality. IRO and Orbis have now agreed to make this course a permanent part of residency training, with all second- and finalyear residents participating annually in October.
Distance wet lab mentorship courses are currently being replicated at Orbis partner hospitals in Bolivia and Haiti, teaching the manual small incision cataract surgical technique. Based on the positive user feedback, it appears that structured distance wet lab courses in phacoemulsification are acceptable to ophthalmologists in training.

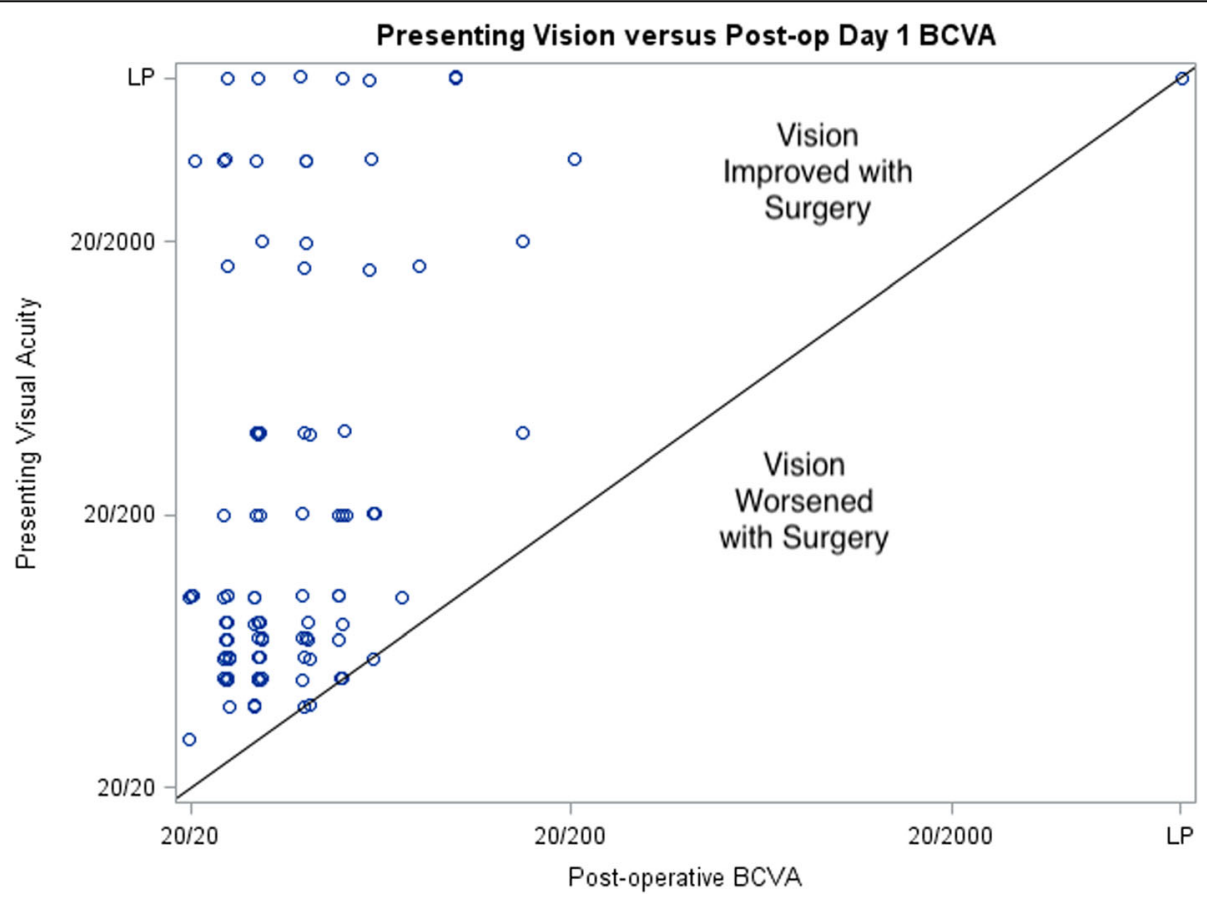

Fig. 2 Presenting visual acuity versus post-operative day one best corrected visual acuity (BCVA) 
Tele-education or distance learning is widely used in academic training today. By 2006-07, 61\% of US higher education institutions offered some form of online courses [10]. It is likely that this number has continued to rise, as online education provides greater costefficiency and allows access to learners in remote locations [10]. There is evidence of better performance among students who engage in flipped classrooms or blended-learning, defined as approaches combining inperson and online activities. A group of medical students at Zhongshan Ophthalmic Center who received online lectures and resources during their ophthalmology clerkships performed better on subsequent examinations and reported improved motivation and understanding of the material in comparison to a group who attended traditional classroom-based lectures [11]. The University of Miami Miller School of Medicine integrated flipped courses for students of ophthalmology, after which students performed better in examinations than in four previous semesters where typical teaching methods were applied [23]. Additionally, ophthalmologists recruited in Brazil, Mexico and the Philippines who were trained in the diagnosis of retinopathy of prematurity through a structured tele-education course showed significantlyimproved diagnostic accuracy and reliability, and reported a preference for tele-education to traditional teaching methods [12].

Wet lab education is also a common teaching method and found in many current ophthalmic residency programs. An ophthalmologist experiences the highest complication rates during the first $60-80$ surgical cases [13, 14, 22], while evidence demonstrates that structured cataract surgical simulation courses can reduce the complication rates in these initial operations [16]. Simulation training of micro-surgical skills has shown improved performance outcomes [24]. Training using model eyes has shown improvements in both the accuracy and speed for surgically naïve residents in performing capsulorhexis and corneal sutures [25] and improvements in corneal suturing were also found with experienced cornea surgeons [26]. Dean et al.'s demonstrated that intense simulation based cataract surgical education using models eyes resulted in improved surgical competence, as well as improved live surgical performance and reduced surgical complication rates [22].

The use of the virtual reality cataract surgical simulator Eyesi (VRmagic, Mannheim, Germany) has also shown improved performance among cataract surgery trainees [27]. Eyesi cataract simulation training has shown improvements in resident ophthalmologists' confidence in performing phacoemulsification [28]. A Royal College of Ophthalmologists' National Ophthalmology database study of nearly 18,000 cases performed by firstand second-year residents showed a 38\% reduction in posterior capsule rupture rates for residents who'd undergone simulation training compared to trainees who did not receive this form of simulation training [29]. However, the Eyesi system is cost prohibitive for many residency programs in LMICs, both in terms of initial purchase and annual costs to maintain the license and support contract, and therefore has not been widely adopted.

Combining these two effective teaching models by delivering wet lab training through distance learning, the program described in the current paper was able to realize improved performance outcomes.

Despite the effectiveness of simulation training, ophthalmic residents in low and middle-income countries, as well as high-income countries have inadequate simulation surgical courses [30, 31]. Some of the reasons reported were lack of structured or poorly organized simulation training programs; lack of simulation facilities; lack of trained instructors or personnel, disinterest in training residents from consultants, particularly for residents assigned to peripheral hospitals rather than teaching hospitals for clinical practice; high volume of residents due to government mandates, and outpacing the faculty available for teaching [32].

The model presented in this paper suggests that this approach is an effective way to improve the cataract surgical skills of trainees. Further, this model could provide a viable alternative method for delivering wet lab cataract surgical training in locations where some of the reported challenges to wet lab training, such as structured programs, limited faculty, and lack of access to training institutions, undermine the delivery of in-person structured wet lab courses.

Another consideration is the recent Corona virus disease (COVID-19) pandemic, which resulted in many ophthalmology departments closing or severely reducing their patient volume. This coupled with the need to practice social distancing, left many residents with limited access to traditional in-person hands-on training and clinical learning opportunities, essentially disrupting surgical training at a global level [33]. During COVID19 , many medical training institutions were forced to rethink how they delivered education, and explore the use of virtual teaching, distance learning and simulation, to meet the training needs of their learners [34]. Distance wet lab courses also offer the opportunity to provide continuity of training, respecting the need for social distancing, during disruptive events such as COVID-19. The University of California, San Francisco recently delivered a distance wet lab in corneal suturing, in which faculty and residents reported the session equally and/or more effective than previous in-person wet lab training in corneal suturing [35]. 
Regarding the difficulty of the different steps in phacoemulsification surgery, Dooley et al. [36] reported on 8 trainee surgeons' assessment of the difficulty of 8 individual stages of phacoemulsification cataract surgery, after performing 100 consecutive surgeries. The trainees reported phacoemulsification and Continuous Curvilinear Capsulorhexis (CCC), as the most complicated stages, which also had the lowest completion rates (66.7 and $74.4 \%$ respectively). This was followed by irrigation/ aspiration and IOL insertion, with completion rates of 78.4, and $83.1 \%$, respectively. Similar results have been reported from mentors (evaluated) and trainees (selfassessed/reported), with phacoemulsification and CCC consistently reported as the most challenging steps to learn [37-39]. Our analysis showed that residents most significantly improved in lens insertion, rotation and final position of IOL, irrigation and aspiration technique with adequate removal of cortex and capsulorhexisformation and circular completion. Five additional steps showed significant improvements $(p<0.05)$ including nucleus cracking or chopping. This indicates that the distance wet lab training is associated with improvements in intermediate to challenging surgical steps.

\section{Conclusions}

Positive user feedback and the significant improvement in surgical performance based on masked assessment of videos by an experienced grader (RJ) suggest that distance wet lab mentorship courses can be an effective training tool in this setting. Further work is needed in other settings to confirm these results.

\section{Abbreviations \\ BCVA: Best Corrected Visual Acuity; CCC: Continuous Curvilinear Capsulorhexis; COVID - 19: Corona Virus Disease 2019; ICO: International Council of Ophthalmology; IOL: Intraocular Lens; IRO: Instituto Regional De Oftalmología; LMICs: Low- and Middle-Income Countries; LMS: Learning Management System; OSCAR: Ophthalmology Surgical Competency Assessment Rubric; OSSCAR: Ophthalmology Simulation Surgical Competency Assessment Rubric; WHO: World Health Organization}

\section{Acknowledgements}

We'd like to acknowledge the leadership and staff of the Instituto Regional De Oftalmología Javier Servat Univazo.

\section{Authors' contributions}

Amelia Geary: Research Design, Research Execution, Data analysis and manuscript preparation. Qing Wen: Data analysis and interpretation. Rosa Adrianzén MD: Research design and data acquisition. Nathan Congdon: Research design, manuscript preparation. R. Janani MD: Data analysis and interpretation. Danny Haddad: Research design. Clare Szalay Timbo: Manuscript preparation. Yousuf M. Khalifa MD: Research Design, Research Execution, and manuscript preparation. All authors approve the submission of the manuscript.

\section{Funding}

The work was supported by Orbis International, a non-governmental organization, registered in New York, NY, USA. Professor Congdon is supported by the Ulverscroft Foundation, UK.
Availability of data and materials

The datasets used and/or analyzed during the current study are available from the corresponding author on reasonable request.

\section{Declarations}

Ethics approval and consent to participate

Ethics approval was obtained from the Institutional Review Board at IRO, written consent was obtained from the leadership of IRO and the tenets of the Declaration of Helsinki were followed throughout.

\section{Consent for publication}

All participants consented to the research study and publication of research results.

\section{Competing interests}

None

\section{Author details}

1'Orbis International, 520 8th Avenue, Floor 12, New York, NY 10018, USA. ${ }^{2}$ Centre for Public Health, Queen's University Belfast, Belfast BT12 6BJ, Northern Ireland. ${ }^{3}$ Instituto Regional de Oftalmología Javier Servat Univazo, Trujillo, La Libertad, Peru. ${ }^{4}$ Universidad Nacional de Trujillo, Trujillo, La Libertad, Peru. ${ }^{5}$ Aravind eye hospital, Madurai, Tamil Nadu 625020, India.

${ }^{6}$ Emory Eye Center, Emory University, Atlanta, GA, USA.

Received: 11 November 2020 Accepted: 5 April 2021

Published online: 19 April 2021

\section{References}

1. Resnikoff S, Felh W, Gauthier T, Spivey B. The number of ophthalmologists in practice and training worldwide: a growing gap despite more than 200 000 practitioners. Br J Ophthalmol. 2012;96(6):783-7. https://doi.org/10.1136/ bjophthalmol-2011-301378.

2. Bourne R, Flaxman S, Braithwaite T, et al. Magnitude, temporal trends, and projections of the global prevalence of blindness and distance and near vision impairment: a systematic review and meta-analysis. Lancet Glob Health. 2017;5(9):e888-97. https://doi.org/10.1016/s2214-109x(17)30293-0.

3. Flaxman SR, Bourne RRA, Resnikoff S, Ackland P, Braithwaite T, Cicinelli MV, et al. Global causes of blindness and distance vision impairment 1990-2020: a systematic review and meta-analysis. Lancet Glob Health. 2017:5(12): e1221-34. https://doi.org/10.1016/S2214-109X(17)30393-5.

4. Sommer A, Taylor HR, Ravilla TD, West S, Lietman TM, Keenan JD, et al. Challenges of ophthalmic care in the developing world. JAMA Ophthalmol. 2014;132(5):640-4. https://doi.org/10.1001/jamaophthalmol.2014.84.

5. Lindfield R, Vishwanath K, Ngounou F, Khanna RC. The challenges in improving outcome of cataract surgery in low and middle income countries. Indian J Ophthalmol. 2012;60(5):464-9. https://doi.org/10.4103/03 01-4738.100552.

6. Botman $M$, Meester $R$, Voorhoeve $R$, et al. The Amsterdam declaration on essential surgical care. World J Surg. 2015;39(6):1335-40. https://doi.org/10.1 007/s00268-015-3057-x.

7. Young A, Jhanji V, Liang $Y$, et al. A survey of perceived training differences between ophthalmology residents in Hong Kong and China. BMC Med Educ. 2015;15(1). https://doi.org/10.1186/s12909-015-0440-0.

8. Thomas R, Dogra M. An evaluation of medical college departments of ophthalmology in India and change following provision of modern instrumentation and training. Indian J Ophthalmol. 2008;56(1):9-16. https:// doi.org/10.4103/0301-4738.37589

9. Jiang Y, Luo L, Congdon N, Wang S, Liu Y. Who will be wielding the lancet for China's patients in the future? Lancet. 2016;388(10054):1952-4. https:// doi.org/10.1016/S0140-6736(16)31792-5.

10. Bernard R, Borokhovski E, Schmid R, Tamim R, Abrami P. A meta-analysis of blended learning and technology use in higher education: from the general to the applied. J Comput High Educ. 2014;26(1):87-122. https://doi.org/10.1 007/s12528-013-9077-3.

11. Tang F, Chen C, Zhu Y, et al. Comparison between flipped classroom and lecture-based classroom in ophthalmology clerkship [published correction appears in Med Educ Online. 2017;22(1):1406198]. Med Educ Online. 2017; 22(1):1395679. https://doi.org/10.1080/10872981.2017.1395679. 
12. Campbell JP, Swan R, Jonas K, et al. Implementation and evaluation of a tele-education system for the diagnosis of ophthalmic disease by international trainees. AMIA Annu Symp Proc. 2015;2015:366-75 Published 2015 Nov 5.

13. Randleman JB, Wolfe JD, Woodward M, Lynn MJ, Cherwek DH, Srivastava SK. The resident surgeon phacoemulsification learning curve. Arch Ophthalmol. 2007;125(9):1215-9. https://doi.org/10.1001/archopht.125.9.1215.

14. Ministerio de Salud. Plan Nacional Concertado De Salud. Peru; 2007.

15. Ministerio de Salud. PERU Estimaciones Y Proyecciones De La Población Total Por Años Y Edades Simples 1950-2050, Dirección General De Epidemiologia.; 2009.

16. Repository | RAAB Repository. Raabdata.info. http://raabdata.info/repository/. Accessed 1 Jul 2018

17. Instituto Regional De Oftalmologia Statistics Department. Health Management Information System [Data File]. Trujillo: Peru Instituto Regional De Oftalmologia; 2017

18. Rogers GM, Oetting TA, Lee AG, Grignon C, Greenlee E, Johnson TA, et al. Impact of a structured surgical curriculum on ophthalmic resident cataract surgery complication rates. J Cataract Refract Surg. 2009;35(11):1956-60. https://doi.org/10.1016/j.jcrs.2009.05.046.

19. Simulated Ocular Surgery. http://simulatedocularsurgery.com/. Accessed 18 Jan 2017.

20. International Council of Ophthalmology: Resources : Surgical Assessment Tool: ICO-OSCAR in English, Mandarin Chinese, Portuguese, Russian, Spanish, Thai, Vietnamese, and French. Icoph.org. http://www.icoph.org/resources/23 0/Surgical-Assessment-Tool-ICO-OSCAR-in-English-Chinese-PortugueseRussian-Spanish-Thai-Vietnamese-and-French.html. Accessed 7 Jan 2017.

21. World Health Organization. Informal Consultation On Analysis Of Blindness Prevention Outcomes. Geneva: World Health Organization; 1998. https://a pps.who.int/iris/handle/10665/67843.

22. Dean WH, Gichuhi S, Buchan JC, Makupa W, Mukome A, Otiti-Sengeri J, et al. Intense simulation-based surgical education for manual small-incision cataract surgery: the ophthalmic learning and improvement initiative in cataract surgery randomized clinical trial in Kenya, Tanzania, Uganda, and Zimbabwe. JAMA Ophthalmol. 2021;139(1):9-15. https://doi.org/10.1001/ja maophthalmol.2020.4718.

23. Green D. Next-generation medical education: facilitating student-centered learning environments. Educause Learning Initiative(ELI); 2016. https://library. educause.edu/resources/2016/3/next-generation-medical-education. Accessed 3 Aug 2020.

24. Chen X, Sikder S, Srikumaran D, Mir T, Woreta F. Outcomes of residentperformed complex cataract surgeries over time. [PowerPoint Presentation]. Austin: Association of University Professors of Ophthalmology Annual Meeting: 2018.

25. Chaku M, Griffin S, Sabherwal N, Khanna A. Taking wet lab microsurgical skills training beyond cataract surgery for ophthalmology residents. [PowerPoint Presentation]. Austin: Association of University Professors of Ophthalmology Annual Meeting; 2018.

26. Steinegger $\mathrm{K}$, Dirani $\mathrm{A}$, Bergin $\mathrm{C}$ et al. Assessment of the BIONIKO prosthetic surgical training tools. Invest Ophthalmol Vis Sci. 2015;56(7):136.

27. Bisol T, Renata RB, Rezende F. Efficacy of Eyesi surgical simulator training in improving high-tension capsules capsulorhexis performance. Rev Bras Oftalmol. 2016;75:376-9. https://doi.org/10.5935/0034-7280.20160075.

28. $\mathrm{Ng} \mathrm{DS}$, Sun $\mathrm{Z}$, Young $\mathrm{AL}$, et al. Impact of virtual reality simulation on learning barriers of phacoemulsification perceived by residents. Clin Ophthalmol. 2018;12:885-93. Published 2018 May 11. https://doi.org/10.214 7/OPTH.S140411.

29. Ferris JD, Donachie PH, Johnston RL, Barnes B, Olaitan M, Sparrow JM. Royal College of Ophthalmologists' National Ophthalmology Database study of cataract surgery: report 6 . The impact of EyeSi virtual reality training on complications rates of cataract surgery performed by first and second year trainees. Br J Ophthalmol. 2020 Mar;104(3):324-9. https://doi.org/10.1136/ bjophthalmol-2018-313817.

30. Al-Salem KM, Al-Sarayra FA, Abu Al-Dabaat M, et al. Ophthalmology residency training in Jordan: an evaluation of quality and comparison with international standards. Int J Ophthalmol. 2014;7(5):898-904. Published 2014 Oct 18. https://doi.org/10.3980/j.issn.2222-3959.2014.05.28.

31. Pandey SK, Sharma V. Cataract surgery training during ophthalmology residency in India: challenges and how to overcome them? Indian J Ophthalmol. 2017;65(12):1279-80. https://doi.org/10.4103/ijo.IJO_1032_17.
32. Gibson A, Boulton MG, Watson MP, Moseley MJ, Murray PI, Fielder AR. The first cut is the deepest: basic surgical training in ophthalmology. Eye (Lond) 2005;19(12):1264-70. https://doi.org/10.1038/sj.eye.6701754

33. Das De S, Puhaindran M, Sechachalam S, Wong K, Chong C, Chin A. Sustaining a national surgical training programme during the COVID-19 pandemic. Bone Joint Open. 2020;1(5):98-102. https://doi.org/10.1302/204 6-3758.15.bjo-2020-0019.

34. Plancher K, Shanmugam J, Petterson S. The changing face of orthopedic education: searching for the new reality after COVID-19. Arthrosc Sports Med Rehabil. 2020;2(4):e295-8. https://doi.org/10.1016/j.asmr.2020.04.007.

35. Pasricha ND, Haq Z, Ahmad TR, et al. Remote corneal suturing wet lab: microsurgical education during the COVID-19 pandemic [published online ahead of print, 2020 Aug 5]. J Cataract Refract Surg. 2020. https://doi.org/1 0.1097/j.jcrs.0000000000000374.

36. Dooley IJ, O'Brien PD. Subjective difficulty of each stage of phacoemulsification cataract surgery performed by basic surgical trainees. J Cataract Refract Surg. 2006;32(4):604-8. https://doi.org/10.1016/j.jcrs.2006.01.045.

37. Saxena R, Sen S, Patil M, et al. Perceived difficulties and complications in learners of phacoemulsification: a principal component analysis model. Indian J Ophthalmol. 2019;67(2):213-6. https://doi.org/10.4103/ijo.ijo_1133_18.

38. Al-Jindan M, Almarshood A, Yassin S, Alarfaj K, Al Mahmood A, Sulaimani N. Assessment of learning curve in phacoemulsification surgery among the Eastern province ophthalmology program residents. Clin Ophthalmol. 2020; 14:113-8. https://doi.org/10.2147/opth.s241250.

39. Taravella M, Davidson R, Erlanger M, Guiton G, Gregory D. Characterizing the learning curve in phacoemulsification. J Cataract Refract Surg. 2011:37(6): 1069-75. https://doi.org/10.1016/j.jcrs.2010.12.054.

\section{Publisher's Note}

Springer Nature remains neutral with regard to jurisdictional claims in published maps and institutional affiliations.

Ready to submit your research? Choose BMC and benefit from:

- fast, convenient online submission

- thorough peer review by experienced researchers in your field

- rapid publication on acceptance

- support for research data, including large and complex data types

- gold Open Access which fosters wider collaboration and increased citations

- maximum visibility for your research: over $100 \mathrm{M}$ website views per year

At $\mathrm{BMC}$, research is always in progress.

Learn more biomedcentral.com/submission 